\title{
A NEW SPECIES OF PLEUROTHALLIS (ORCHIDACEAE: PLEUROTHALLIDINAE) IN SUBSECTION MACROPHYLLAE-FASCICULATAE WITH A UNIQUE, HIGHLY REDUCED, MORPHOLOGICALLY DISTINCT LABELLUM
}

\author{
Mark Wilson ${ }^{1,7}$, Kehan ZhaO ${ }^{1}$, Hailey Hampson ${ }^{1}$, Graham Frank ${ }^{1}$, \\ Katya Romoleroux ${ }^{2}$, Marco Jiménez ${ }^{3,5}$, Francisco Tobar ${ }^{4,5}$, Bruno Larsen ${ }^{6}$ \\ \& Állvaro J. PÉrez
}

${ }^{1}$ Department of Organismal Biology and Ecology, Colorado College, Colorado Springs, CO 80903, U.S.A. ${ }^{2}$ Herbario QCA, Escuela de Ciencias Biológicas, Pontificia Universidad Católica del Ecuador

${ }^{3}$ Av. del Ejército y Juan Izquierdo, 190102, Zamora, Ecuador

${ }^{4}$ Verde.ec, Arupos, E2 y Av. Yaloman, Quito, Ecuador

${ }^{5}$ Instituto Nacional de Biodiversidad, Quito, Ecuador

${ }^{6}$ Constitutiestraat 94, 2060 Antwerp, Belgium

${ }^{7}$ Author for correspondence: mwilson@coloradocollege.edu

Abstract. Pleurothallis minutilabia, a species unique in subsection Macrophyllae-Fasciculatae because of the minute, highly reduced lip, is described and compared to the most similar species in the subsection. It is also compared morphologically to Pleurothallis kaynagata from section Abortivae, to which P. minutilabia is not related, but which also possesses a highly reduced lip. The morphology of the flower of P. minutilabia is discussed briefly in relation to possible pollination mechanisms. The distribution, restricted to Zamora Chinchipe, southern Ecuador, and the conservation status are addressed.

KEY wORDS: cloud forest, Ecuador, labellar morphology, Pleurothallis, pollination

Introduction. Within Pleurothallis R.Br. as circumscribed by Pridgeon et al. (2005), subsection Macrophyllae-Fasciculatae Luer represents the largest taxonomic group with between 236 and 305 described species, depending on synonymy (Wilson, unpubl.). A consistent characteristic among all the species of Pleurothallis subsection MacrophyllaeFasciculatae described to date, without exception, is a prominent and conspicuous labellum or "lip" laying flat upon the synsepal or elevated slightly above it (Fig. 1), which was illustrated in detail for Pleurothallis castanea Mark Wilson, G.Merino \& J.D.Werner, Pleurothallis nangaritzae M.M.Jiménez, Tobar \& Mark Wilson and Pleurothallis rubrifolia Mark Wilson, Tobar \& Salas Guerr. by Wilson et al. (2016). While the dimensions, morphology, texture and positioning of this lip vary among the species, the presence of such a visible lip is constant (Fig. 1). There are currently no described species of Pleurothallis in subsection Macrophyllae-Fasciculatae with a highly reduced or apparently "vestigial" lip.

The first species of Pleurothallis to be described with a minute and apparently vestigial lip was Pleurothallis abortiva Luer (Fig. 2a; Luer 1980). Not fitting well morphologically within any other section or subsection within subgenus Pleurothallis, Luer (1986) created section Abortivae to include $P$. abortiva and a few other species. Subsequently, Luer (1988) removed all but P. abortiva from the section, rendering it monotypic. Luer (1998) retained the monotypic section and stated that $P$. abortiva "is distinguished from all other species of the subgenus by the small, vestigial lip". The section remained monotypic until Doucette et al. (2016) described Pleurothallis kaynagata A.Doucette, Mark Wilson \& J.Portilla which has a similar lip (Fig. 2b, 3, 4).

Until recently, $P$. abortiva (Fig. 2a) and $P$. kaynagata (Fig. 2b, 3, 4) of section Abortivae 


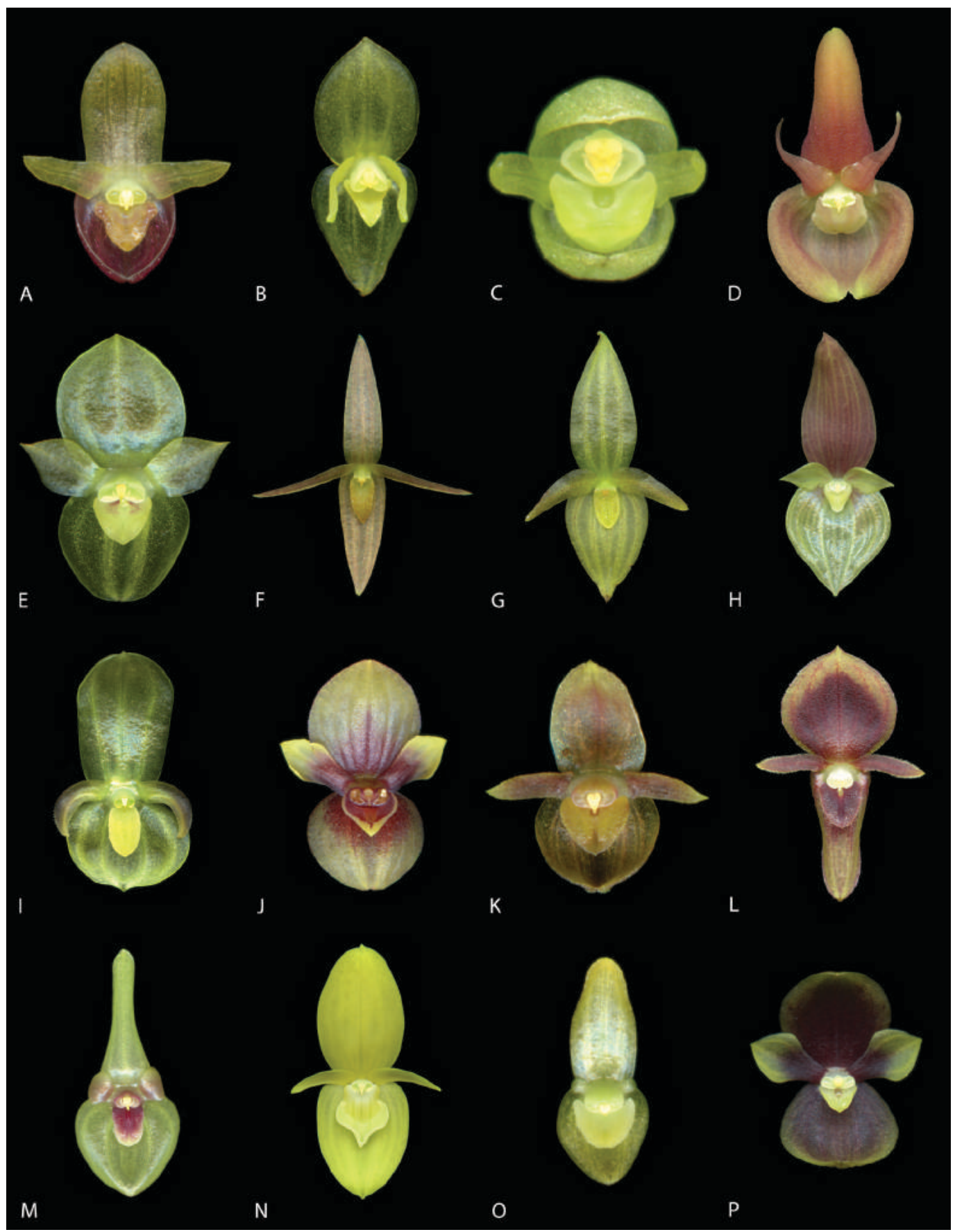

FIGURE 1. Flowers of various species of Pleurothallis subsection Macrophyllae-Fasciculatae demonstrating the prominent, clearly visible lip of the group. A. P. arctata. B. P. baudoensis. C. P. calamifolia. D. P. calceolaris. E. P. conicostigma. F. P. crucifera. G. P. depressa. H. P. latipetala. I. P. octavioi. J. P. ortegae. K. P. pansamalae. L. P. platysepala. M. P. scurrula. N. P. titan. O. P. tridentata. P. P. volans. Prepared from floral scans of plants in the Living Collection at Colorado College by M. Wilson. (Lips presented at the bottom, although some of these species are non-resupinate. Flowers not to the same scale.) 

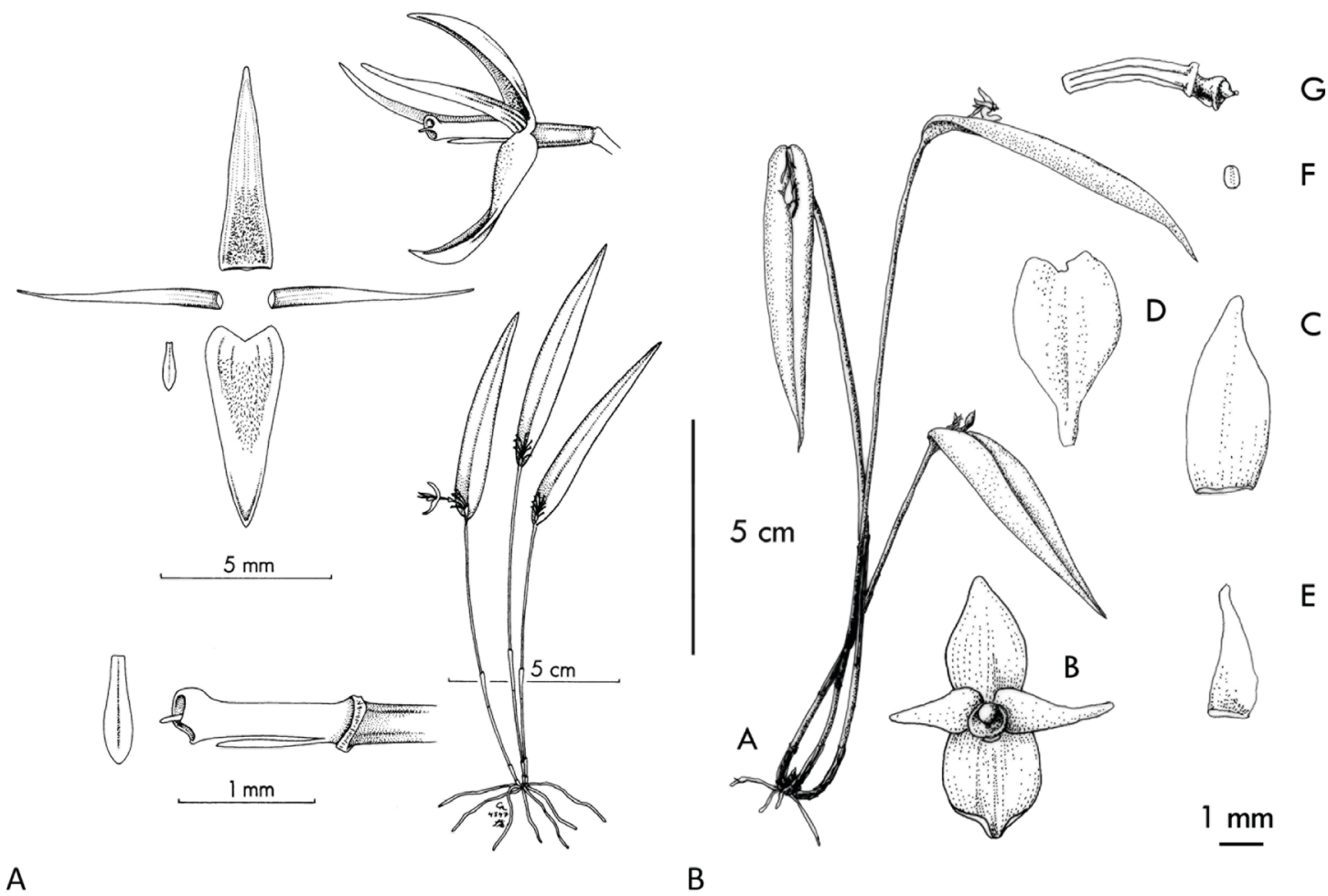

A

B

Figure 2. Drawings of A. Pleurothallis abortiva (drawing reproduced from Luer 1980, courtesy of Missouri Botanical Garden Press); and B. Pleurothallis kaynagata (drawing reproduced from Doucette et al. 2016, courtesy of Sociedad Colombiana de Orquideología and the journal Orquideología).

remained the only known Pleurothallis species with a minute, highly reduced and apparently vestigial lip, none existing in any of the other taxonomic groups within Pleurothallis sensu Pridgeon et al. (2005). The only thing remotely comparable being the very small, highly modified lips of the $P$. crocodiliceps species complex of subgenus Ancipitia (Wilson et al. 2017a, 2017b, 2018). However, in 2015 an undescribed species of Pleurothallis was collected from Podocarpus National Park during an intensive survey of poorly collected areas of Ecuador (Muchhala \& Pérez 2015, Pérez et al. 2016, Orozco et al. 2017). The species was brought to the attention of Wilson because of the minute lip and the remarkable, though superficial, resemblance to P. kaynagata; the difference being that, based on the cordate leaves and bilobed stigma, the new species was most likely attributable to subsection MacrophyllaeFasciculatae, not section Abortivae.

As stated above, all species of subsection
Macrophyllae-Fasciculatae described to date possess a prominent lip. The vast majority of these exhibit a "glenion" on the hypochile below and slightly in front of the anther/rostellum, which is hypothesized to provide a reward, though this has yet to be conclusively demonstrated. Further, many species in the subsection have been observed in vivo with a liquid substance on the lip (Wilson, unpubl.). These observations suggest the probable importance of the glenion and the nectar-like liquid in pollinator attraction and positioning during pollination (Luer 1986, Wilson et al. 2016). Therefore, any species with a highly reduced and apparently vestigial lip are of interest because they may exhibit a very different pollination syndrome from other members of the subsection. In this paper, the new species is described and illustrated and we present an hypothesis regarding the possible role of the unique labellar morphology in the reproductive ecology of the species. 

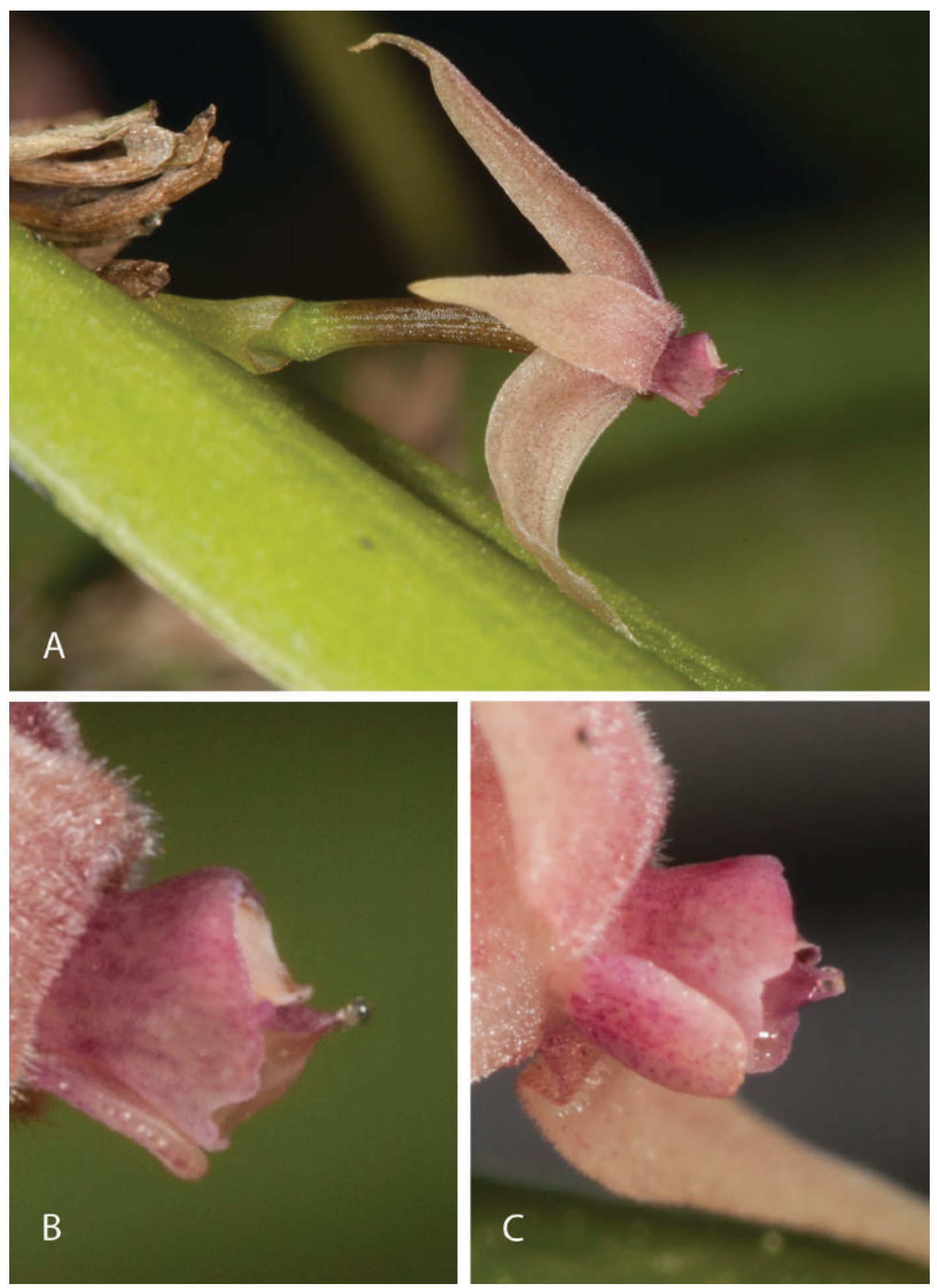

Figure 3. Pleurothallis kaynagata. A. Whole flower - lateral view. B. Column and lip - lateral view. C. Column and lip ventral view. Prepared by M. Wilson from material in Ecuagenera collection. 


\section{Materials and Methods}

Plant material. - Living material of the putative new species was examined in situ in Ecuador by Tobar, Pérez, Romoleroux and Jiménez and in a private collection in The Netherlands by Wilson.

Morphological and taxonomic comparisons. Since the new species was believed to be a member of subsection Macrophyllae-Fasciculatae, in order to determine taxonomic novelty the material was compared with all described species in that subsection. The new species was also compared in detail with Pleurothallis kaynagata from section Abortivae using material from the living collection at Colorado College (Wilson PL0734 and PL0735) and Pleurothallis abortiva from the type, drawings and description since no living material or photographs are known. Finally, the new species was compared with those described in subsection Acroniae, in case the species had mistakenly been published in that group.

Scanning electron microscopy. - For scanning electron microscopy (SEM) fresh-harvested flowers were preserved in Kew Mix (5\% formalin [37.6\% formaldehyde], $53 \%$ methanol, $5 \%$ glycerol, $37 \%$ deionized water). Flowers were dehydrated in successively higher concentrations of ethanol $(80 \%$, $95 \%, 100 \%, 100 \%$ ) for $15 \mathrm{~min}$ each before being placed in freshly-opened $100 \%$ ethanol. Specimens were dried in a critical point dryer (model EMS 850, Electron Microscopy Sciences, Hatfield, PA, USA) prior to mounting on aluminum stubs and sputter coating (model Pelco SC-6, Ted Pella, Redding, CA, USA). Specimens were imaged using a scanning electron microscope (model JSM-6390LV, Jeol, Peabody, MA, USA) with an accelerating voltage of $10-15 \mathrm{kV}$.

\section{Results}

Morphological and taxonomic comparisons. Exhaustive examination of all the published taxonomic literature for subsection Macrophyllae-Fasciculatae, section Abortivae and subsection Acroniae confirmed the novelty of the species. While attributable to subsection Macrophyllae-Fasciculatae based upon the cordate leaves spreading horizontally from the ramicaul and the bilobed stigma, the floral morphology

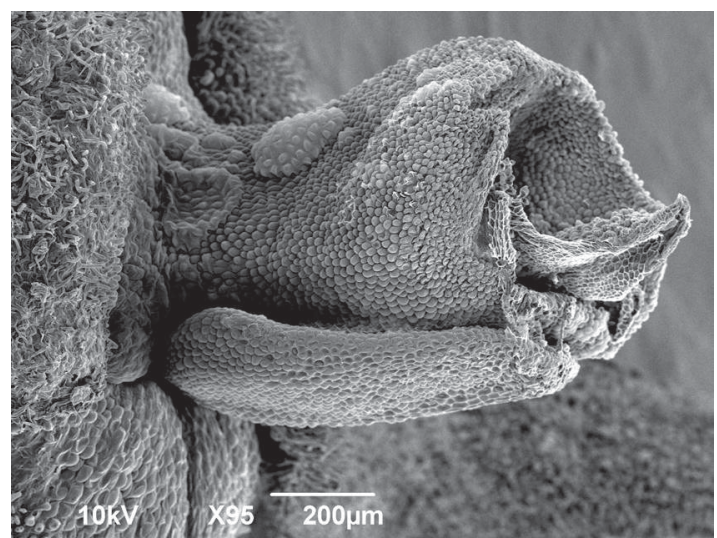

FIGURE 4. Scanning electron micrograph of Pleurothallis kaynagata column and lip. Prepared by G. Frank and M. Wilson from P. kaynagata PL0734 from living collection at Colorado College.

with the highly reduced and apparently vestigial lip indicates that the new species, to date, is unique in the subsection. The lip initially appears to be absent when the flower is viewed from the dorsal surface. Indeed, at first glance it resembles a flower in which the lip has been removed by a slug or snail, as occurs somewhat frequently. The lip becomes visible beneath the column only when the flower is tilted backwards (Fig. 5) or the flower is viewed from the side. Interestingly, the lip was observed to be loosely hinged and partially motile, though the point of articulation on the column was not visible. A flat, triangular flange projecting from the base of the lip appeared to limit the range of motility by resting against the synsepal.

Scanning electron microscopy. - Considering the uniqueness of the floral morphology, a detailed SEM examination was warranted (Figs. 6-9). When imaged from above, the lip is completely obscured by the column and projecting anther (Fig. 6a), but is exposed, nestled beneath the column, when the flower is tilted (Fig. 6b). The lip approximates an equilateral triangle, $\sim 538 \mu \mathrm{m}$ wide at the base and $\sim 520 \mu \mathrm{m}$ long, and is $\sim 285 \mu \mathrm{m}$ deep at the base, assuming minimal shrinkage during critical point drying (Figs. 7 and 8). The lip is subtended at its base by a downward projecting triangular extension, or flange, $\sim 436 \mu \mathrm{m}$ long (from point of attachment to the tip) or $\sim 560 \mu \mathrm{m}$ (from dorsal surface of lip to tip of flange) (Figs. 7 and 8). The most prominent feature is a papilla-lined cavity at the apex of the lip, $\sim 78 \mu \mathrm{m}$ 


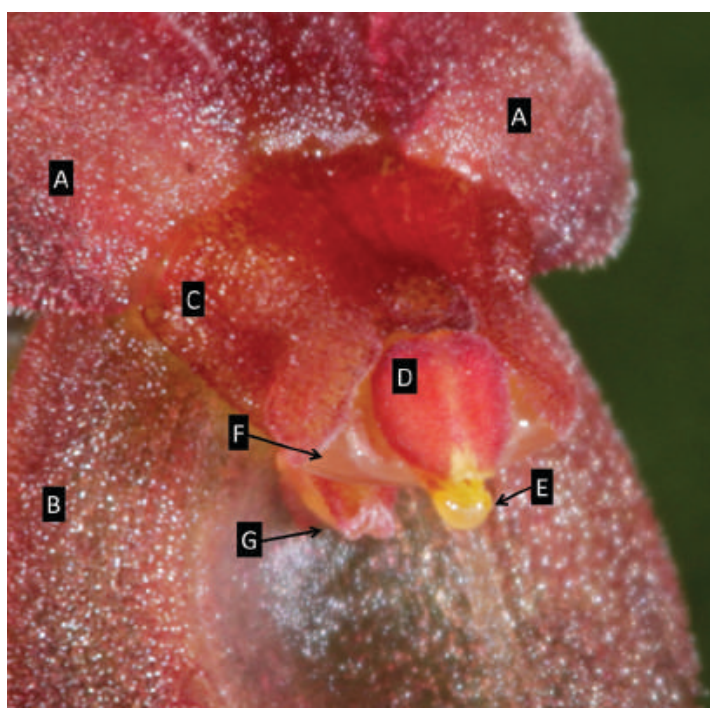

Figure 5. Pleurothallis minutilabia column and lip. A.

Petals. B. Synsepal. C. Column. D. Anther cap. E. Viscidium. F. Stigma. G. Lip. Photograph by M. Wilson from Wilson PL0996.

wide, which appears to project backwards into the lip, creating a ridge along the dorsal surface (Figs. 7 and 8). While the dorsal surface was not completely visible, no glenion or other morphologically-distinct possibly secretory tissue was visible.

The pollinarium is typical for subsection Macrophyllae-Fasciculatae, consisting of two clavate pollinia, $522 \times 264 \mu \mathrm{m}$, subtended by caudicles, with a spherical viscidium at the apex (Fig. 9).

\section{TAXONOMY}

Pleurothallis minutilabia Mark Wilson, F.Tobar, A.J.Pérez, sp. nov. (Figs. 5-11).

TYPE: Ecuador. Zamora-Chinchipe. Podocarpus National Park, Bombuscaro River sector, collected on the trail to the outlook, $1000-1400 \mathrm{~m}, 04^{\circ} 06^{\prime} 38.9^{\prime \prime} \mathrm{S}$, 78 58'11.9'W, 31 Mar 2015 (fl, flower in alcohol), $A$. J. Pérez, F. Tobar, N. Zapata, W. Santillán, H. Namcela 8539 (holotype QCA - 237066).

In subsection Macrophyllae-Fasciculatae, the most morphologically similar species is Pleurothallis erythrium Luer. The new species is easily distinguished from $P$. erythrium by the lip (ovate-triangular, approximately $50 \%$ the length of the synsepal, with
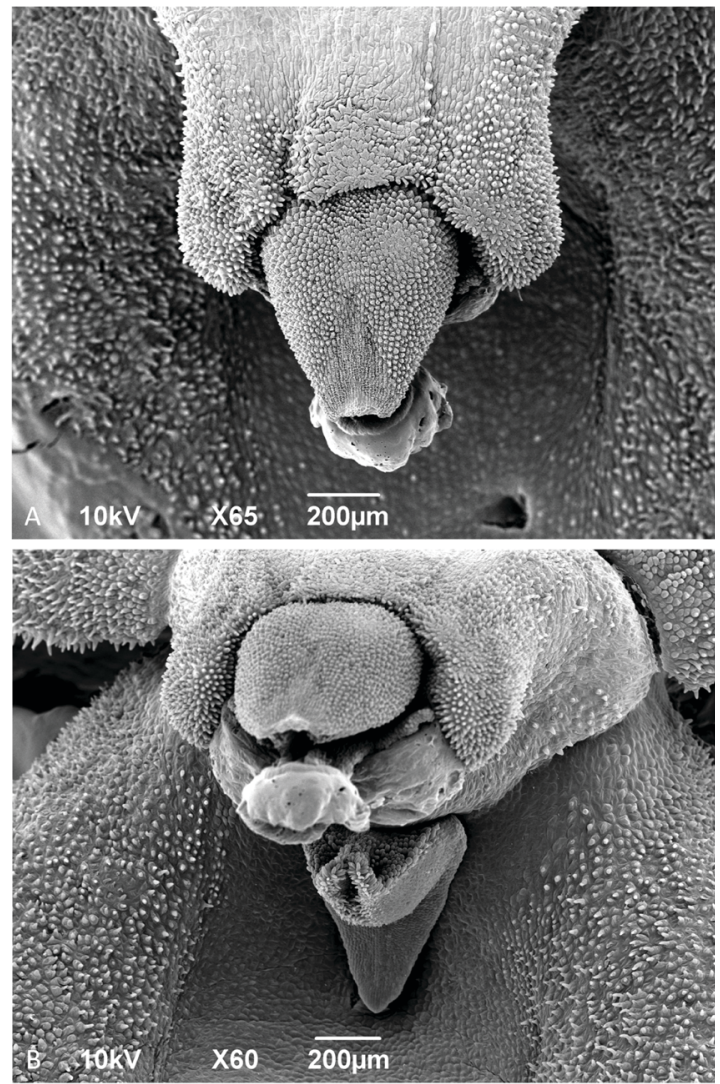

FiguRE 6. Pleurothallis minutilabia scanning electron micrographs. A. Column, anther cap, viscidium and synsepal (dorsal view). B. Column, lip and synsepal (tilted front view). Micrographs by M. Wilson from Wilson PL0996.

distinct glenion in P. erythrium versus highly reduced, not projecting beyond the column, glenion apparently absent and apical, papilla-lined cavity in P. minutilabia) and the surface of the petals and sepals (hirsute in $P$. minutilabia versus glabrous in $P$. erythrium).

Plant epiphytic, caespitose, to $\sim 8-10 \mathrm{~cm}$ tall. Roots fibrous, slender. Ramicauls slender, terete, suberectspreading, 5.4-11.6 cm long, enclosed by thin, papery, tubular sheaths, basal sheath $3.2-5.8 \mathrm{~mm}$ long, midramicaul sheath $13-17 \mathrm{~mm}$ long. Leaves horizontal, ovate, acute, $2.0-3.8 \times 1.2-2.8 \mathrm{~cm}$, base sessile, shallowly cordate, coriaceous. Inflorescence fascicle of successive, single flowers, $6.0-7.8 \times 4.3-4.9 \mathrm{~mm}$, resupinate, borne from reclining spathaceous bract $3.8-6.0 \mathrm{~mm}$ long, pedicel $2.5-2.9 \mathrm{~mm}$ long, ovary $1.8-2.2 \mathrm{~mm}$ long. Dorsal sepal beige suffused with 

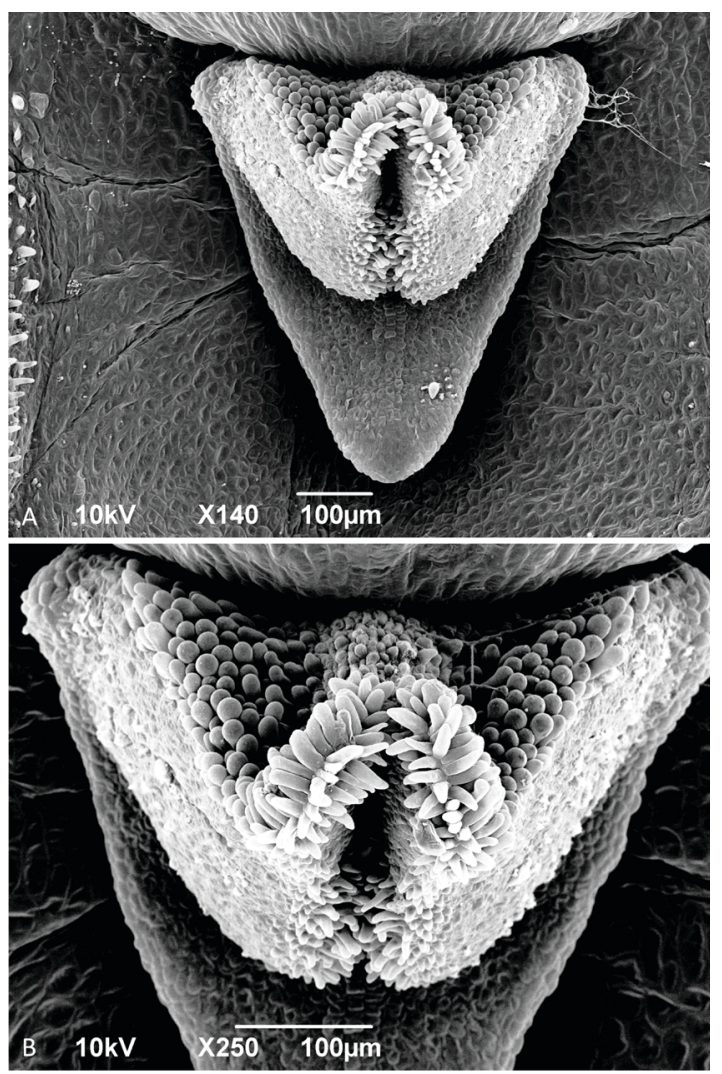

FiguRE 7. Pleurothallis minutilabia scanning electron micrographs. A. Lip with flange (front view). B. Lip (front view). Micrographs by K. Zhao and M. Wilson from Wilson PL0996.

red-purple, ovate, subacute, $3.4-4.0 \times 2.2-2.9 \mathrm{~mm}$, 3 -veined, pubescent. Synsepal beige suffused with red-purple, ovate, subacute, $2.9-3.5 \times 2.7-3.0 \mathrm{~mm}$, concave centrally, 2-veined, pubescent. Petals beige suffused with red-purple, ovate-lanceolate, acute 3.1$3.3 \times 1.0-1.1 \mathrm{~mm}$, one-veined, pubescent. Labellum rufous, triangular, slightly wider than long, $520 \times 538$ $\mu \mathrm{m}$, stout, $285 \mu \mathrm{m}$ thick, concave dorsally, involute ("hooked") apex, keeled ventrally, flat flange projecting downwards from underside of base, $436 \mu \mathrm{m}$ (from point of attachment on underside to tip). Column rufous, stout, 1.0-2.0 $\times 1.2-1.4 \mathrm{~mm}$, papillose, anther apical, stigma bilobed, ventral. Pollinarium two clavate pollinia $522 \times$ $264 \mu \mathrm{m}$, short caudicle, spherical viscidium.

Additional material studied: The Netherlands. Heijningen, flowered in cultivation without collection data, December 2017, Wilson PL0996 (paratype: COCO).
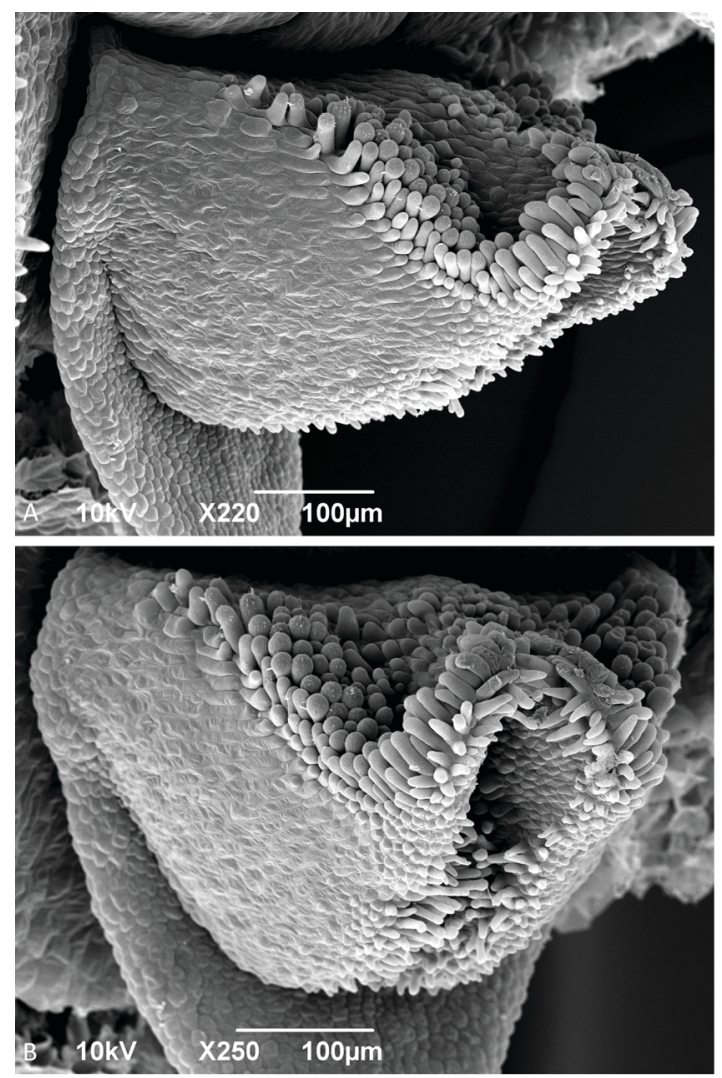

FiguRE 8. Pleurothallis minutilabia scanning electron micrographs. A. Lip (lateral $3 / 4$ view). B. Lip (lateral 2/3 view). Micrographs by H. Hampson from Wilson PL0996.

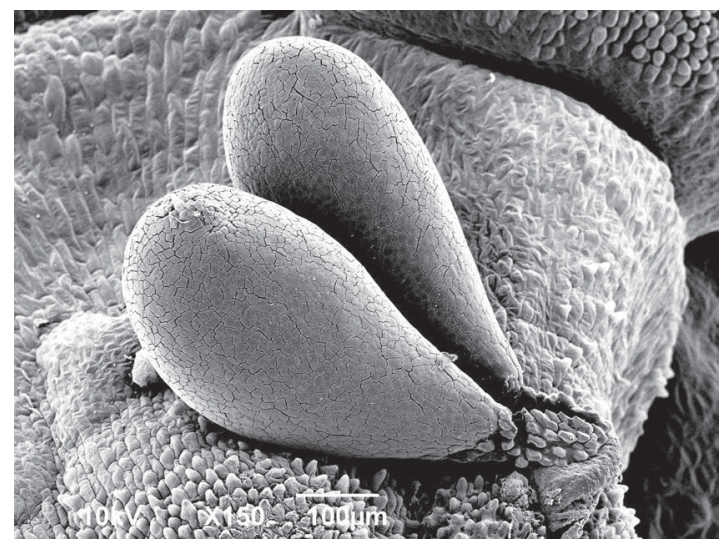

FIgURE 9. Scanning electron micrographs of Pleurothallis minutilabia pollinarium. Micrograph by K. Zhao and M. Wilson from Wilson PL0996.

Etymology: Named for the minuscule size of the lip. 
A
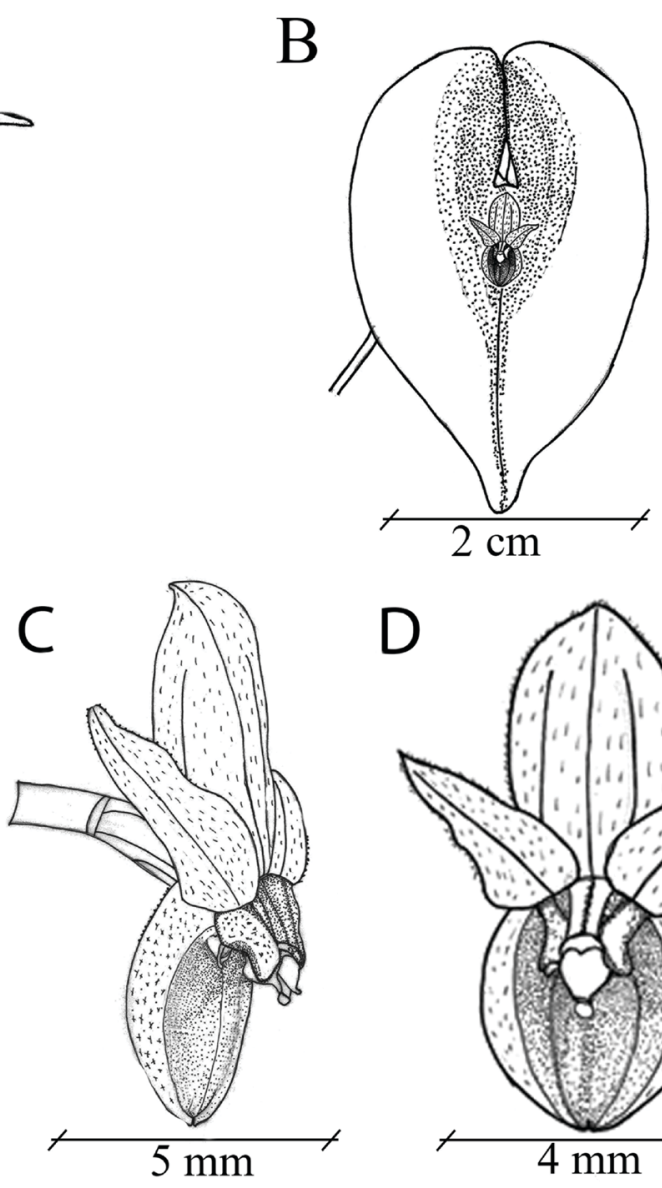

$\mathrm{E}$
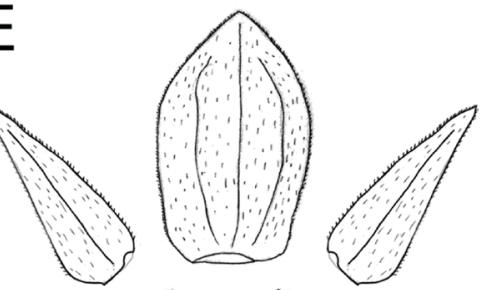

$\mathrm{F}$
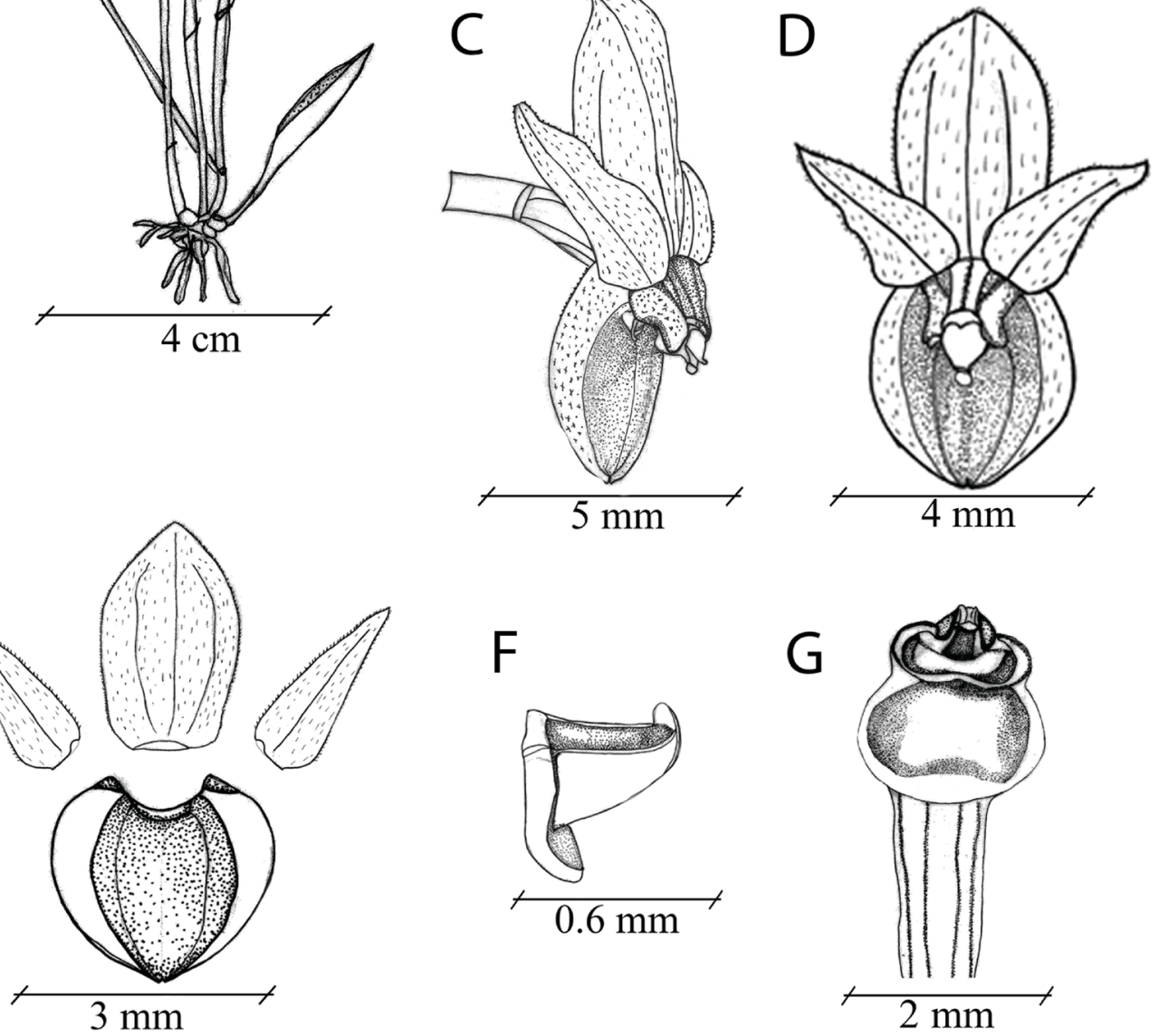

Figure 10. Drawing of Pleurothallis minutilabia: A. Whole plant. B. Leaf with flower. C. Flower (3/4 view). D. Flower

(front view). E. Floral dissection. F. Labellum. G. Column and ovary (ventral surface). Illustration by F. Tobar and K. Romoleroux, from material used to prepare the type specimen.

Pleurothallis minutilabia is placed in the group Macrophyllae-Fasciculatae (Luer 1986, 1988, 2005) based on morphological attributes: spreading-to-erect, well-developed ramicauls; sessile, cordate leaves, not in same plane as ramicaul; single-flowered inflorescence emerging from the apex of the ramicaul at the base 


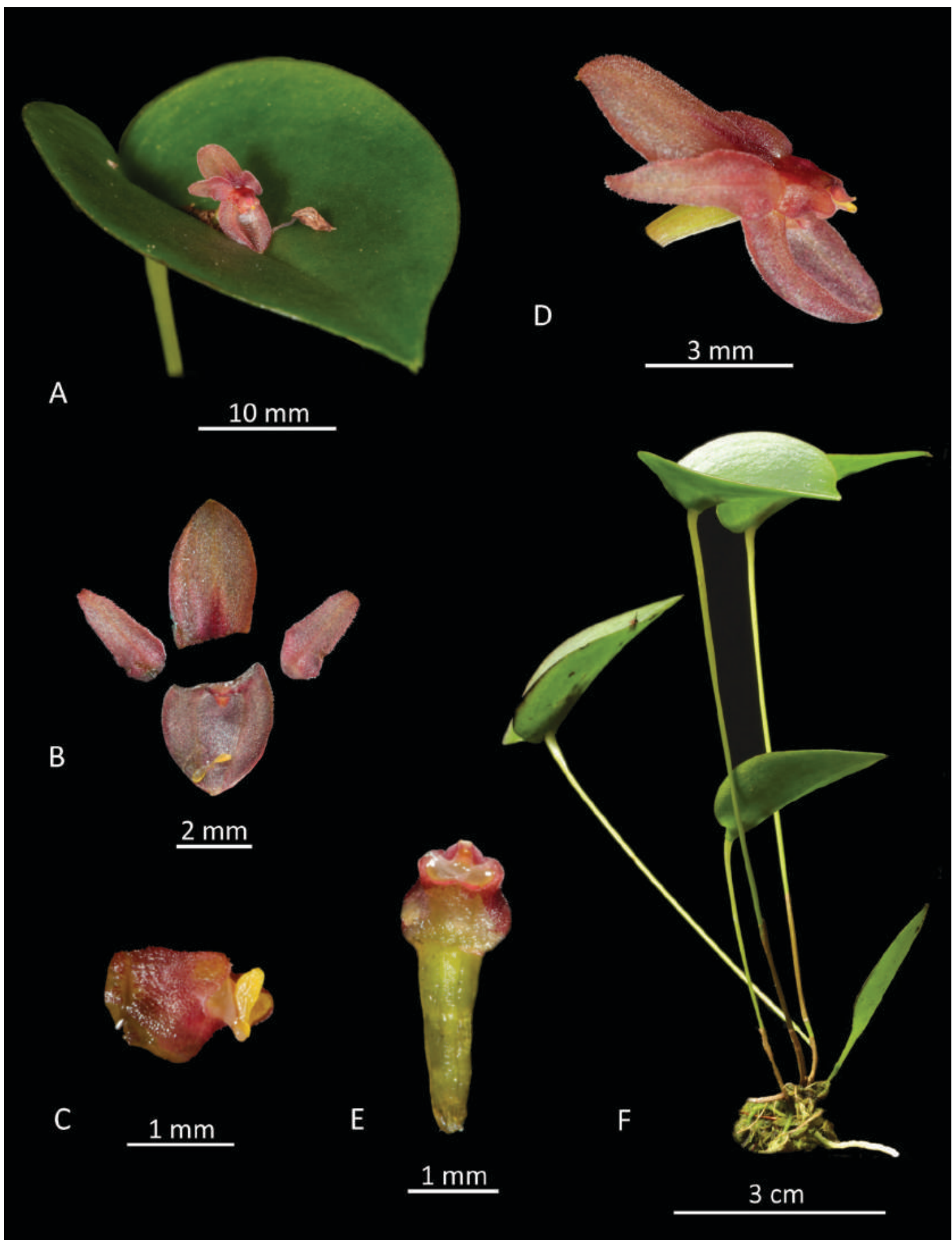

Figure 11. Pleurothallis minutilabia Lankester composite dissection plate. A. Leaf and flower. B. Floral dissection - sepals and petals. C. Column. D. Whole flower - lateral view. E. Column and ovary - ventral view. F. Whole plant. LCDP prepared by M. Wilson from Wilson PL0996. 


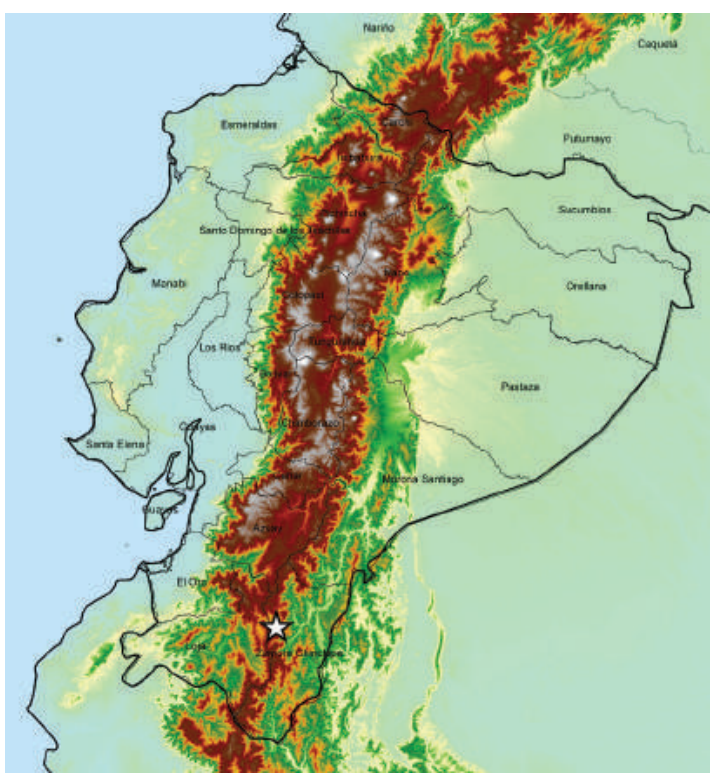

FiguRE 12. Pleurothallis minutilabia distribution map indicating type locality (white star). Map prepared by H. Hampson.

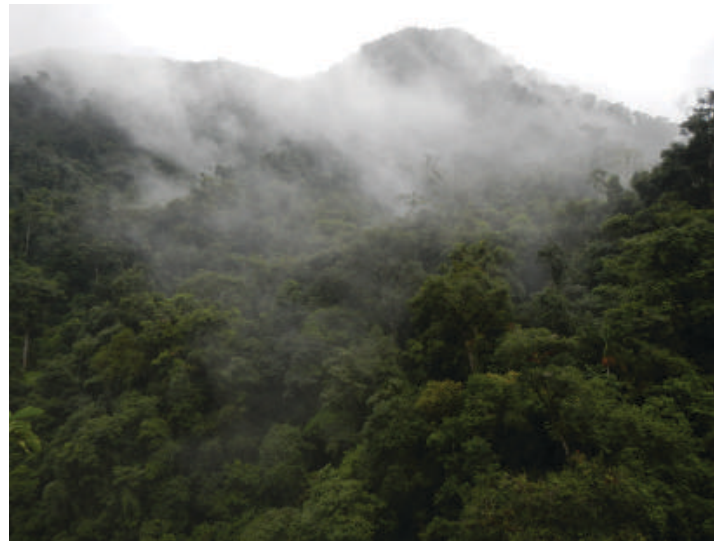

FIgURE 13. Pleurothallis minutilabia habitat in Podocarpus National Park. Photograph by Á. J. Pérez.

of the leaf; short peduncle and pedicel mostly hidden within the reclining spathaceous bract; apical anther; and transversely bilobed stigma. Morphologically $P$. minutilabia does not fit within section Abortivae (Luer 1980, 1998) or within the single-flowered subsection Acroniae series Amphigyae Luer (Luer 1998), because these species typically have less well developed ramicauls; sessile, but rarely cordate leaves, usually in the sample plane as the ramicaul; a longer, terete column; longer peduncles and pedicels emerging some distance from the spathaceous bract; and an oval, rather than bilobed, stigmatic surface.

Whilenotclosely related, the flowers of Pleurothallis minutilabia (Macrophyllae-Fasciculatae) and Pleurothallis kaynagata (Abortivae) are superficially similar and could be confused. Pleurothallis minutilabia is, however, easily distinguished by the leaves (ovate, acute, sessile, cordate in P. minutilabia versus lanceolate, acute, tridenticulate apex, sessile, cuneate in $P$. kaynagata) and the stigma (bilobed in $P$. minutilabia versus oval in P. kaynagata).

Distribution AND habitat: Pleurothallis minutilabia is an endemic species from Zamora Chinchipe in the southeast of Ecuador, on the eastern slope of the Andes, only known from two collections in the vicinity of Zamora (Fig. 12). It grows in cloud forest (Fig. 13), between 1000-1400 m, which, according to the Ministerio del Ambiente de Ecuador (2013), lies within a much larger zone dominated by evergreen forest in the foothills of the southern Cordillera Oriental of the Andes ("bosque siempreverde piemontano del sur de la cordillera oriental de los Andes" (BsPn04)). This species is sympatric with Pleurothallis aff. undulata Poepp. \& Endl. and Pleurothallis cardiostola Rchb.f. from subsection MacrophyllaeFasciculatae and the tree species Centronia laurifolia D.Don (Melastomataceae), Ocotea longifolia Kunth (Lauraceae) and Guatteria pastazae R.E.Fr. (Annonaceae).

Conservation status: Pleurothallis minutilabia appears to have a very restricted distribution and may be endemic to the province of Zamora Chinchipe. The type locality is in the Parque Nacional Podocarpus, an area of ca. $1500 \mathrm{~km}^{2}$ protected since 1982 . The second locality, however, somewhat to the west of Zamora, is not in a protected area. Further data are required on the distribution and abundance of this species before a valid conservation assessment can be made. Hence, the species should be listed as Data Deficient according to IUCN (2012) criteria until such an assessment can be made.

Discussion. Vegetative and floral morphological characters place Pleurothallis minutilabia within section Pleurothallis subsection MacrophyllaeFasciculatae (Luer 1988) and not within section Abortivae (Luer 1980, 1998) or subsection Acroniae 

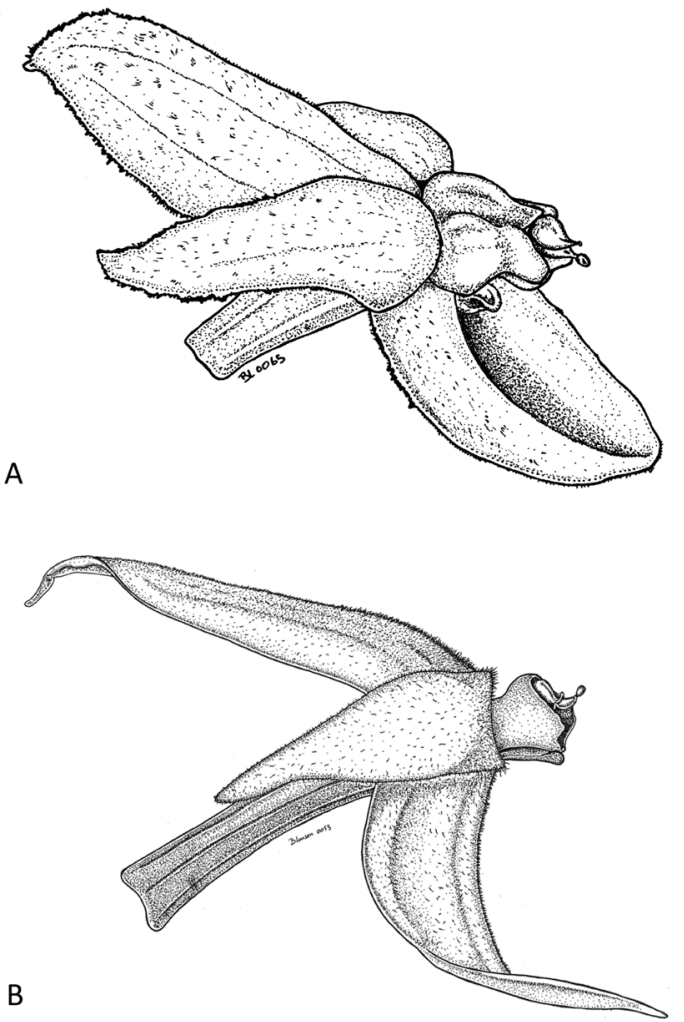

FIgure 14. A. Pleurothallis minutilabia flower (lateral view). B. Pleurothallis kaynagata flower (lateral view). Illustrations by B. Larsen from Wilson PL0996 and Wilson PL0734, respectively.

series Amphigyae (Luer 1998), the only two other possible groups. The labellar morphology of $P$. minutilabia is completely unique within the subsection. Of the 236+ species described to date, all possess a small-to-large lip which projects beyond the column (Fig. 1); of those examined so far, the vast majority possess a glenion on the lip; and many have been observed with a liquid substance somewhere on the lip (Wilson et al., unpubl.). In P. minutilabia, however, the lip is completely obscured until the flower is tilted backwards or sideways to reveal the minute, highly reduced structure beneath the column. The only parallel is in the apparently vestigial lips of $P$. abortiva and P. kaynagata (Figs. 2-4).

Following the taxonomy of Luer, Pleurothallis kaynagata would be attributable to section Abortivae. However, Doucette et al. (2016) hypothesized that the closest relative is Pleurothallis neossa (Luer \& Hirtz) J.M.H.Shaw of subsection Acroniae, which has been borne out by recent phylogenetic analysis (Wilson, unpubl.). Although Luer (2005) chose to combine subsections Macrophyllae-Fasciculatae and Acroniae under the resurrected name Acronia C.Presl., preliminary phylogenetic analyses indicate that the two groups are phylogenetically distinct (Wilson et al. 2011, 2013).

Although not closely related, flowers of $P$. minutilabia and $P$. kaynagata are morphologically similar (Fig. 14): both flowers are beige, lightly suffused with burgundy; both flowers are hirsute, uniformly covered in short hairs (a characteristic rare within Macrophyllae-Fasciculatae); both flowers are relatively open, with reflexed petals; and, both have a short column with a highly reduced lip. The lip of P. minutilabia at $\sim 520 \times 538 \mu \mathrm{m}$ (or $\sim 0.5 \times$ $0.5 \mathrm{~mm}$ ), however, is significantly smaller than that of $P$. abortiva $1.6 \times 0.5 \mathrm{~mm}$ (Luer 1980) or that of $P$. kaynagata $1.0 \times 0.7 \mathrm{~mm}$ (Doucette et al. 2016). And, the lip of P. minutilabia is very different in morphology from those of the other two species. While the lips of $P$. abortiva and P. kaynagata are ovate, membranous and adpressed to the ventral surface of the column (Luer 1980, Doucette et al. 2016) (Figs. 2-4), the lip of $P$. minutilabia is stout, triangular, concave dorsally, with a papilla-lined cavity at the apex (Figs. 6-8). Further, the lip has a flat, triangular flange at the base of the lip which lies against the synsepal and appears to maintain the position of the lip in the vertical plane.

Luer (1998) referred to the lip of Pleurothallis abortiva as "vestigial". According to the Oxford Living Dictionary vestigial can be defined as: "degenerate, rudimentary, or atrophied, having become functionless in the course of evolution" and according to the MerriamWebster dictionary the definition is: "remaining in a form that is small or imperfectly developed and not able to function". In both definitions, loss of function is a central concept. We hypothesize that, at least in Pleurothallis minutilabia, the highly reduced, but morphologically unique and structurally complex lip is not vestigial according to these definitions. The micromorphology of the lip revealed by SEM, including the papilla-lined, apical labellar cavity and the supporting flange seem far too elaborate to comprise a vestigial structure. We hypothesize, therefore, that the lip of P. minutilabia performs a very specific function during the reproductive ecology of the species. 


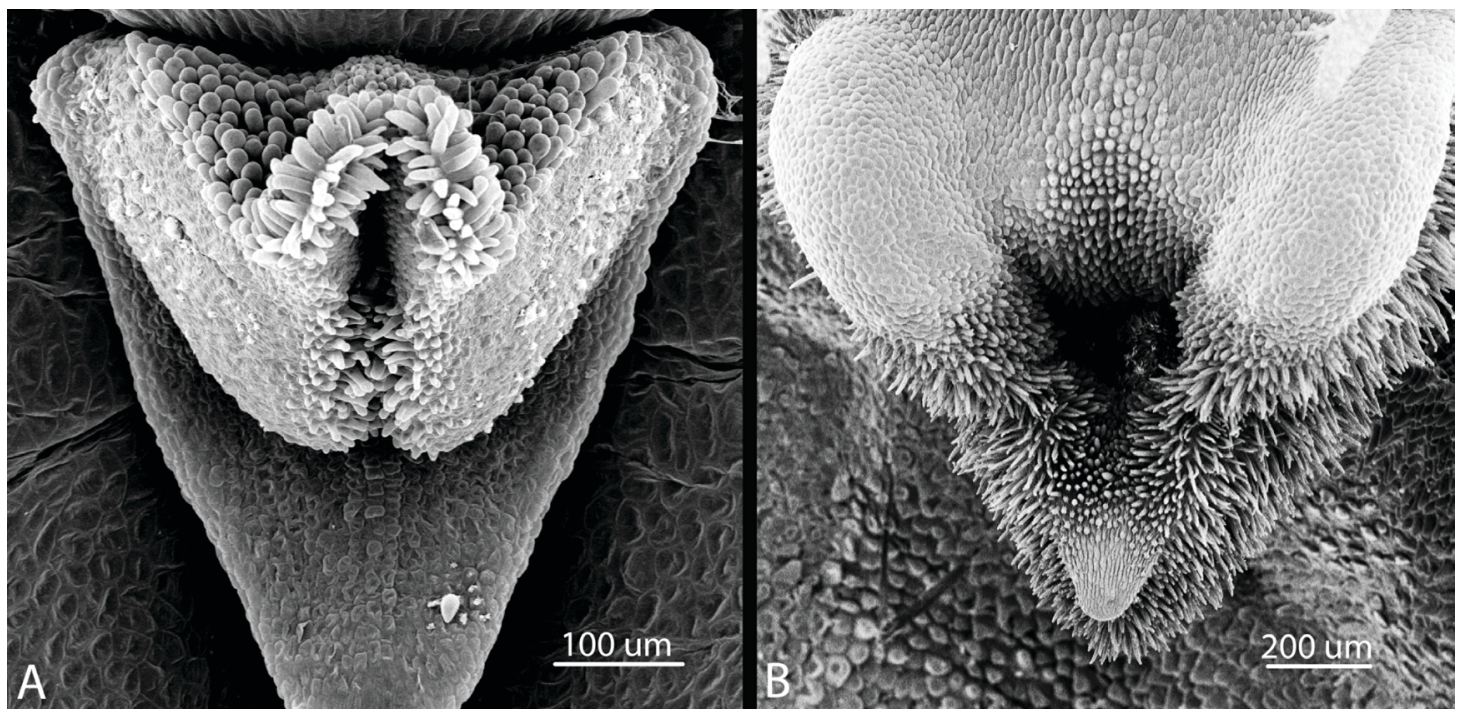

Figure 15. Papilla-lined, apical labellar cavities. A. Pleurothallis minutilabia. B. Pleurothallis wielii. Scanning electron micrographs by K. Zhao, K. Dupree and M. Wilson.

The last two decades have seen substantial progress in the study of pollination strategies in Pleurothallidinae, including in the genera Acianthera Scheidw. (Borba \& Semir 2001); Andinia (Luer) Luer (Álvarez 2011); Dracula Luer (Endara et al. 2010, Policha et al. 2016); Lepanthes Sw. (Blanco \& Barboza 2005, Blanco \& Vieira 2011, Calderón-Sáenz 2012); Restrepia Kunth (Millner \& Baldwin 2016); Specklinia Lindl. (Karremans et al. 2015); and Trichosalpinx Luer (Bogarín et al. 2018). In comparison to these other Pleurothallidinae much less is known about pollination strategies in Pleurothallis, with only a few careful studies having been published (Calderón-Sáenz 2011, Damon \& Salas-Roblero 2007, Díaz-Morales \& Karremans 2015, Duque-Buitrago et al. 2014) and only one of these being of a species in subsection Macrophyllae-Fasciculatae (Duque-Buitrago et al. 2014). Nevertheless, we can observe that in almost all species of Pleurothallis subsection MacrophyllaeFasciculatae, there is a distinct lip projecting beyond the column; typically with a glenion on the hypochile; and a liquid substance, a probable pollinator reward, is often observed on the lip (Wilson et al. unpubl.). The lip of P. minutilabia is unique among the 236+ species of the subsection and, therefore, one might conclude, functions differently than the other lips.

We hypothesize that Pleurothallis minutilabia is deceit-pollinated through pseudocopulation by a male insect and that the lip plays a specific, important role in the process. To date, among Pleurothallidinae, pseudocopulation has been observed only in Andinia (Álvarez 2011) and Lepanthes (Blanco \& Barboza 2005, Blanco \& Vieira 2011, Calderón-Sáenz 2012) and, admittedly, apart from reduced size, there are no morphological similarities between the lips of these species and that of P. minutilabia that would support this hypothesis. However, the extreme reduction in size despite morphological complexity; the apical papillalined cavity into which the abdomen of an insect could be inserted; and the labellar motility modulated by the subtending flange all suggest to us a possible pseudocopulatory role for the lip. Interestingly, the papilla-lined cavity of $P$. minutilabia strongly resembles the cavity in the lips of the $P$. crocodiliceps complex (Fig. 15) (Wilson et al. 2017a, 2017b, 2018), which are also hypothesized to involve deceitpollination by pseudocopulation. Acknowledging that only in situ observations of the pollination process can conclusively demonstrate deceitpollination by pseudocopulation in P. minutilabia, given the difficulty of performing such studies in a sparsely distributed, tropical montane species, in the meantime additional studies are planned to address the hypothesis. These include light microscopy of labellar sections with staining for possible reward chemicals; transmission electron microscopy of labellar sections 
to further examine the apical labellar cavity; and gas chromatography-mass spectroscopy (GC-MS) to examine floral volatiles.

We further hypothesize that the phylogenetically unrelated Pleurothallis kaynagata is also deceitpollinated through pseudocopulation and that floral morphological similarities between $P$. kaynagata and $P$. minutilabia represent convergent evolution due to similar pollination syndromes. The reproductive ecology of $P$. minutilabia, $P$. kaynagata and the $P$. crocodiliceps species complex and the hypothesized involvement of deceit pollination via pseudocopulation is one area of ongoing research in the Wilson lab.
Acknowledgements. MW, KZ, HH and GF thank Colorado College and Robert Hevey for research funding and Colorado College for provision of greenhouse, herbarium, electron microscopy and GIS facilities; Dr. Ron Hathaway for assistance with scanning electron microscopy; and Matt Cooney for GIS instruction. AP, KR, MJ and FT thank the curators from QCA and QCNE herbaria and Secretaría de Educación Superior, Ciencia, Tecnología e Innovación de la República del Ecuador (SENESCYT, Arca de Noé Initiative; S. R. Ron and O.Torres-Carvajal, main researchers) and the Ecuadorian Ministerio del Ambiente for granting permits MAE-DNB-ARRGG-CM-2014-0002 and MAE-DNB-CM-2016-0045. The authors are grateful to the Editors of Lankesteriana and the anonymous reviewers for suggestions to improve the manuscript.

\section{Literature Cited}

Álvarez, L. E. (2011). Polinización Lepanthes. El Orquideólogo: Boletín de la Asociación Bogotana de Orquideología, 46, $15-16$.

Blanco, M. A. \& Barboza, G. (2005). Pseudocopulatory pollination in Lepanthes (Orchidaceae: Pleurothallidinae) by fungus gnats. Annals of Botany, 95, 763-772. doi: https://doi.org/10.1093/aob/mci090

Blanco, M. A. \& Vieira-Uribe, S. (2011). Pollination in Lepanthes. Orchids, 80(6), 356-357.

Bogarín, D., Fernández, M., Borkent, A., Heemskerk, A., Pupulin, F., Ramírez, S., Smets, E. \& Gravendeel, B. (2018). Pollination of Trichosalpinx (Orchidaceae: Pleurothallidinae) by biting midges (Diptera: Ceratopogonidae). Botanical Journal of the Linnaean Society, 186(3), 510-543. doi: https://doi.org/10.1093/botlinnean/box087

Borba, E. L. \& Semir, J. (2001). Pollinator specificity and convergence in fly-pollinated Pleurothallis (Orchidaceae) species: A multi-population approach. Annals of Botany, 88, 75-88.

Calderón-Sáenz, E. (2011). Pleurothallis colossus: Pollination by Anthomyiid flies at El Refugio Nature Reservation. Orchids, 80(12), 740-743.

Calderón-Sáenz, E. (2012). Remoción de polinarios de Lepanthes yubarta por una mosca fungosa del género Bradysia, bajo condiciones seminaturales. Orquideología, 29(1), 31-34.

Damon, A. \& Salas-Roblero, P. (2007). A survey of pollination in remnant orchid populations in Soconusco, Chiapas, Mexico. Tropical Ecology, 48(1), 1-14.

Díaz-Morales, M. \& Karremans, A. (2015). Pollination biology of five species of Pleurothallidinae in a montane region in Costa Rica. Poster presented at the V Scientific Conference on Andean Orchids, Cali, Colombia, Nov 2015.

Doucette, A., Wilson, M., Portilla, J., Kay, A., Moreno, J. S. \& Cameron, K. M. (2016). Two new species of Pleurothallis and a new name for Acronia rinkei. Orquideología, 23(2), 123-139.

Duque-Buitrago, C. A., Alzate-Quintero, N. F. \& Tupac Otero, J. (2014). Nocturnal pollination by fungus gnats of the Colombian endemic species, Pleurothallis marthae (Orchidaceae: Pleurothallidinae). Lankesteriana, 13(3), $407-417$.

Endara, L., Grimaldi, D. A. \& Roy, B. A. (2010). Lord of the flies: pollination of Dracula orchids. Lankesteriana, 10(1), 1-11. doi: 10.15517/LANK.V10I1.18318

IUCN (2012). The IUCN red list of threatened species, version 2017-1. IUCN Red List Unit, Cambridge U.K. Retrieved from: http://www.iucnredlist.org/ [Accessed 18 Jan 2018].

Karremans, A. P., Pupulin, F., Grimaldi, D., Beentjes, K. K., Bûtot, R., Fazzi, G. E., Kaspers, K., Kruizinga, J., Roessingh, P., Smets, E. F. \& Gravendeel, B. (2015). Pollination of Specklinia by nectar-feeding Drosophila: the first reported case of a deceptive syndrome employing aggregation pheromones in Orchidaceae. Annals of Botany, 116 (3), 437-445. doi: https://doi.org/10.1093/aob/mcv086

Luer, C. A. (1980). Miscellaneous new species in the Pleurothallidinae (Orchidaceae). Phytologia, 47, 59-84.

Luer, C. A. (1986). Icones Pleurothallidinarum III: Systematics of Pleurothallis. Monographs in Systematic Botany, 20, $1-109$.

Luer, C. A. (1988). A revision of some subsections of genus Pleurothallis. Lindleyana, 3, 133-149.

Luer, C. A. (1998). Icones Pleurothallidinarum XVII: Systematics of subgen. Pleurothallis sect. Abortivae, sect. Truncatae, 
sect. Pleurothallis, subsect. Acroniae, subsect. Pleurothallis, subgen. Dracontia, subgen. Unciferia. Monographs in Systematic Botany from Missouri Botanical Garden, 72, 1-121.

Luer, C. A. (2005). Icones Pleurothallidinarum XXVII: Dryadella and Acronia section Macrophyllae-Fasciculatae. Monographs in Systematic Botany from Missouri Botanical Garden, 103, 1-311.

Millner, H. J. \& Baldwin, T. C. (2016). Floral micromorphology of the genus Restrepia (Orchidaceae) and the potential consequences for pollination. Flora, 225, 10-19.

Ministerio del Ambiente del Ecuador. (2013). Sistema de Clasificación de los Ecosistemas del Ecuador Continental. Subsecretaría de Patrimonio Natural, Quito, 232 pp.

Muchhala, N. \& Pérez, A. J. (2015). Burmeistera zamorensis (Campanulaceae, Lobelioideae), a new species from southern Ecuador. Novon, 24, 36-38.

Orozco, C. I., Pérez, A. J., Romoleroux, K. \& Murillo Aldana, J. (2017). The discovery of a new species of Brunellia (Brunelliaceae) with ephemeral petals from Llanganates National Park, Ecuador. Phytotaxa, 311(3), 263-269.

Pérez, A. J., Arroyo, F., Neill, D. A. \& Vázquez-García, J. A. (2016). Magnolia chiguila and M. mashpi (Magnoliaceae): two new species and a new subsection (Chocotalauma, sect. Talauma) from the Chocó biogeographic region of Colombia and Ecuador. Phytotaxa, 284, 267-276. doi: https://doi.org/10.11646/phytotaxa.286.4.5

Policha, T., Davis A., Barnadas, M., Dentinger, B. T. M., Raguso, R. A. \& Roy, B. (2016). Disentangling visual and olfactory signals in mushroom-mimicking Dracula orchids using realistic three-dimensional printed flowers. New Phytologist, 210(3), 1058-1071. doi: https://doi.org/10.1111/nph.13855

Pridgeon, A. M., Cribb, P. J., Chase, M. W. \& Rasmussen, F. N. (2005). Genera Orchidacearum. Vol. 4. Epidendroideae (Part one), (pp. 385-390). Oxford, U.K.: Oxford University Press.

Wilson, M., Baquero, L., Dupree, K., Jiménez, M. M., LeBlanc, C. M., Merino, G., Portilla, J., Salas Guerrero, M., Tobar Suárez, F. \& Werner, J. D. (2016). Three new species of Pleurothallis (Pleurothallidinae; Orchidaceae) in subsection Macrophyllae-Fasciculatae from northern South America. Lankesteriana, 16(3), 349-366. doi: 10.15517/LANK. V16I3.27314

Wilson, M., Belle, C., Dang, A., Hannan, P., Kenyon, C., Low, H., Stayton, T. \& Woolley, M. A. (2011). A phylogenetic analysis of the genus Pleurothallis, with emphasis on Pleurothallis subsection Macrophyllae-Fasciculatae, using nuclear ITS and chloroplast DNA sequencing. Lankesteriana, 11(3), 369. doi: 10.15517/LANK.V1113.18304

Wilson, M., Belle, C., Dang, A., Hannan, P., Kellogg, L., Kenyon, C., Low, H., Mochizuki, A., Nguyen, A., Sheade, N., Shan, L., Shum, A., Stayton, T., Volz, C., Vosburgh, B., Wellman, H. \& Woolley, M. A. (2013). Preliminary phylogenetic analysis of Pleurothallis sensu lato based upon nuclear and plastid sequences. Lankesteriana, 13(1-2), 139. doi: 10.15517/LANK.V0I0.11568

Wilson, M., Dupree, K., Driessen, W., Larsen, B. T., Löckher, A., Niessen, A., Portilla, J., Salas Guerrero, M., Suarez, M. A. \& Tobar Suárez, F. (2017a). A clarification of the taxonomy of Pleurothallis crocodiliceps Rchb.f. (Pleurothallidinae, Orchidaceae) and four new species of Pleurothallis in subgenus Ancipitia. Lankesteriana, 17(2), 165-191. doi: 10.15517/LANK.V1712.29911

Wilson, M., Vieira-Uribe, S., Aguirre, G., Posada, J. F. \& Dupree, K. (2017b). Two new species of Pleurothallis (Pleurothallidinae, Orchidaceae) in subgenus Ancipitia from Colombia. Orquideología, 34, 34-51.

Wilson, M., Jimenez, M. M., Jost, L., Kay, A., Frank, G. \& Baquero, L. E. (2018). A new species of Pleurothallis (Orchidaceae, Pleurothallidinae) from northwestern Ecuador with affinities to both subgenera Ancipitia and Scopula. Phytotaxa, 343(3), 249-258. Doi: http://dx.doi.org/10.11646/phytotaxa.343.3.5 